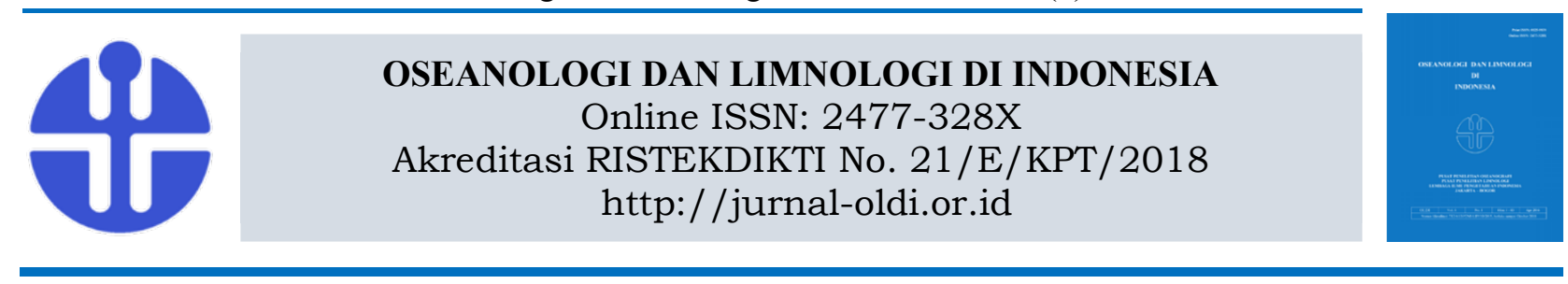

\title{
Isolasi dan Identifikasi Bakteri Toleran Logam Berat dari Sedimen Mangrove di Pengudang dan Tanjung Uban, Pulau Bintan, Indonesia
}

\author{
Charlie Ester de Fretes $^{1 *}$, Lies Indah Sutiknowati ${ }^{1}$, dan Dede Falahudin ${ }^{2}$ \\ ${ }^{1}$ Laboratorium Mikrobiologi Laut, Pusat Penelitian Oseanografi LIPI, Jl. Pasir Putih I, Ancol Timur, Jakarta \\ ${ }^{2}$ Laboratorium Kimia Organik, Pusat Penelitian Oseanografi LIPI, Jl. Pasir Putih I, Ancol Timur, Jakarta \\ Email : *charlie.defretes@gmail.com
}

Submitted 31 January 2019. Reviewed 3 May 2019. Accepted 25 Juny 2019.

DOI: 10.14203/oldi.2019.v4i2.244

\begin{abstract}
Abstrak
Pencarian bakteri untuk remediasi polutan logam berat terus dilakukan karena terus meningkatnya pencemaran di ekosistem akibat industrialisasi. Penelitian ini bertujuan untuk mengidentifikasi strain bakteri toleran terhadap logam berat dari sedimen mangrove yang dilaksanakan di Pengudang dan Tanjung Uban, Pulau Bintan pada tahun 2018. Isolasi bakteri dilakukan dengan metode pour plate dan dipurifikasi menggunakan medium marine agar (MA). Skrining isolat bakteri toleran logam berat dilakukan dengan menumbuhkan isolat pada medium MA dengan penambahan logam $\mathrm{Pb} 100 \mathrm{ppm}$. Selain itu, dilakukan penentuan minimum inhibitory concentration (MIC) logam $\mathrm{Pb}, \mathrm{Cu}$, dan $\mathrm{Cd}$ terhadap isolat bakteri dengan penambahan logam dengan konsentrasi 50-1000 ppm. Identifikasi isolat toleran logam berat dilakukan dengan sekuensing gen 16S rRNA. Hasil isolasi bakteri dari sedimen mangrove diperoleh 48 isolat yang digunakan untuk pengujian kemampuan toleran terhadap logam berat. Uji skrining menunjukkan isolat PGD1A, PGD5A, PGD22A, PGD1B, PGD9B, PGD5C, PGD6C, TJU1, TJU5, dan TJU7 yang bersifat resisten terhadap logam berat. Hasil penelitian menunjukkan bahwa isolat bakteri yang diisolasi dari sedimen mangrove memiliki nilai MIC yaitu 800-900 ppm untuk $\mathrm{Pb}, 100-800$ ppm untuk $\mathrm{Cu}$ dan 100-200 ppm untuk $\mathrm{Cd}$. Terdapat tiga isolat bakteri yang memiliki resistensi yang tinggi terhadap ketiga jenis logam berat yaitu Bacillus oceanisediminis PGD1A, Vibrio alginolyticus PGD5A, dan Halobacillus kuroshimensis PGD9B. Hal ini mengindikasikan bahwa isolat tersebut dapat digunakan secara efisien untuk penghilangan logam berat dari ekosistem.
\end{abstract}

Kata kunci : isolat bakteri, konsentrasi minimum penghambatan, logam berat, gen 16S rRNA.

\section{Abstract}

Isolation and Identification of Heavy Metals Tolerant Bacteria from Mangrove Sediment in Pengudang and Tanjung Uban, Bintan Island, Indonesia. Bacterial searches for remediation of heavy metal pollutants continue to be carried out due to the increasing pollution in the ecosystem as a result of industrialization. This research aims to identification bacteria strains that are tolerant of heavy metals from mangrove sediments in the Pengudang and Tanjung Uban, Bintan Island in 2018. Bacterial isolation was carried out by pour plate method and purified using marine agar (MA) medium. Screening of bacterial isolates was carried out by growing isolates on MA medium with the addition of $100 \mathrm{ppm} \mathrm{Pb}$. In addition, the determination of minimum inhibitory concentration (MIC) was performed on the isolates were tolerant to $\mathrm{Pb}, \mathrm{Cu}$, and $\mathrm{Cd}$ by addition of heavy metals in 50-1000 ppm concentrations. Identification of heavy metal tolerant isolates was carried out by sequencing the $16 \mathrm{~S} r R N A$ gene. The results of bacterial isolation from mangrove sediments obtained 48 isolates used for testing the ability of heavy metals tolerant. Screening tests 
de Fretes et al.

showed that PGD1A, PGD5A, PGD22A, PGD1B, PGD9B, PGD5C, PGD6C, TJU1, TJU5, and TJU7 isolates were heavy metal resistant. The results showed that bacterial isolated from mangrove sediments had MIC values of 800-900 ppm for Pb, 100-800 ppm for Cu and 100-200 ppm for Cd. There are 3 isolates that have high resistance to three kinds of heavy metals such as Bacillus oceanisediminis PGD1A, Vibrio alginolyticus PGD5A, and Halobacillus kuroshimensis PGD9B. This indicates that the isolate can be used efficiently for removal of heavy metals from the ecosystem.

Keywords: bacterial isolates, heavy metals, minimum inhibitory concentration, tolerant, $16 S$ rRNA gene.

\section{Pendahuluan}

Saat ini, pertumbuhan industrialisasi yang pesat telah menyebabkan peningkatan buangan limbah industri ke lingkungan. Akumulasi logam berat pada tanah, air tanah, sedimen, air permukaan dan udara memberikan dampak yang sangat berbahaya. Hal ini disebabkan karena logam berat tidak dapat dipecah oleh organisme menjadi bentuk tidak beracun sehingga memiliki efek jangka panjang pada ekosistem. Konsentrasi yang tinggi pada semua jenis logam berat memiliki efek merusak pada lingkungan (Cheng, 2003). Logam berat beracun seperti $\mathrm{Hg}, \mathrm{Cr}, \mathrm{Cu}$, $\mathrm{Zn}, \mathrm{Pb}$, dan $\mathrm{Cd}$ tidak memiliki peran biologis tetapi memiliki dampak toksisitas, mutagenik serta karsinogenik pada manusia dan organisme lainnya. Asha et al. (2013) telah melakukan pengembangan teknologi baru untuk pemulihan ekosistem terkontaminasi polutan dengan pendekatan teknik degradasi polutan dibandingkan dengan pembuangan konvensional yang berpotensi memasuki rantai makanan.

Mangrove menyediakan ekosistem yang sangat produktif untuk berbagai hewan, tanaman dan mikroorganisme karena memiliki keragaman yang tinggi. Keragaman mikroorganisme tersebut menyebabkan kebutuhan nutrien yang tinggi sehingga mikroorganisme bertanggung jawab terhadap proses degradasi dan pembentukan senyawa penting dalam aliran karbon pada sedimen hutan mangrove (Holguin et al., 2001). Hasil penelitian sebelumnya tentang populasi mikroba menunjukkan bahwa kelompok Alphaproteobacteria mendominasi komunitas bakteri dalam sedimen mangrove yang tidak terganggu (Dias et al., 2010). Selain itu, penelitian oleh Taketani et al. (2010) menunjukkan bahwa akibat adanya paparan minyak mentah pada sedimen mangrove terjadi penurunan populasi kelompok bakteri seperti Anaerolinea dan meningkatnya populasi Deltaproteobacteria. Hal ini menunjukkan bahwa keragaman bakteri pada sedimen mangrove dipengaruhi oleh perubahan faktor lingkungan. Keragaman bakteri di hutan mangrove menunjukkan sumber potensial sumber daya bioteknologi yang baik untuk dieksplorasi, termasuk untuk menemukan spesies baru yang mampu dimanfaatkan dalam bidang industri, pertanian maupun pembersihan ekosistem dari polutan (Dias et al., 2009).

Proses penggunaan mikroorganisme untuk mengurangi konsentrasi polutan dikenal dengan bioremediasi. Bioremediasi merupakan proses alami yang memanfaatkan keanekaragaman hayati untuk pembersihan ekosistem yang tercemar logam, minyak mentah, $\mathrm{PAH}$, dan polutan lainnya. Mikroorganisme memiliki kemampuan untuk menghasilkan metabolit yang mampu mendegradasi polutan kompleks menjadi senyawa yang sederhana. Hal ini disebabkan karena mikroorganisme telah memiliki resistensi untuk bertahan terhadap racun logam berat yang ada di lingkungannya (Thassitou \& Arvanitoyannis, 2001). Berbagai penelitian telah melaporkan mekanisme yang dikembangkan oleh mikroorganisme dalam mendegradasi logam berat antara lain serapan logam, penyerapan dan akumulasi endapan ekstraseluler, mineralisasi dan oksidasi atau reduksi enzimatik menjadi bentuk tidak beracun, serta penghilangan logam berat dari sel (François et al., 2012; Monteiro et al., 2012). Pada penelitian ini, dilakukan uji kemampuan toleransi bakteri yang diisolasi dari sedimen mangrove terhadap beberapa jenis logam berat $(\mathrm{Pb}, \mathrm{Cu}$, dan $\mathrm{Cd})$ sehingga dapat dimanfaatkan sebagai agen hayati dalam degradasi logam berat dari ekosistem yang tercemar.

\section{Metodologi}

\section{Pengambilan sampel sedimen}

Penelitian ini dilakukan di Laboratorium Mikrobiologi Laut Pusat Penelitian Oseanografi LIPI pada bulan Juli sampai dengan November 2018. Sedimen mangrove diperoleh dari daerah perakaran tanaman mangrove di empat stasiun pada dua lokasi yaitu Pengudang dan Tanjung Uban, Pulau Bintan, Indonesia (Gambar 1 dan Tabel 1). Sampel sedimen dimasukkan dalam konikal steril dan diinkubasi pada suhu $4^{\circ} \mathrm{C}$ hingga dibawa ke laboratorium. 


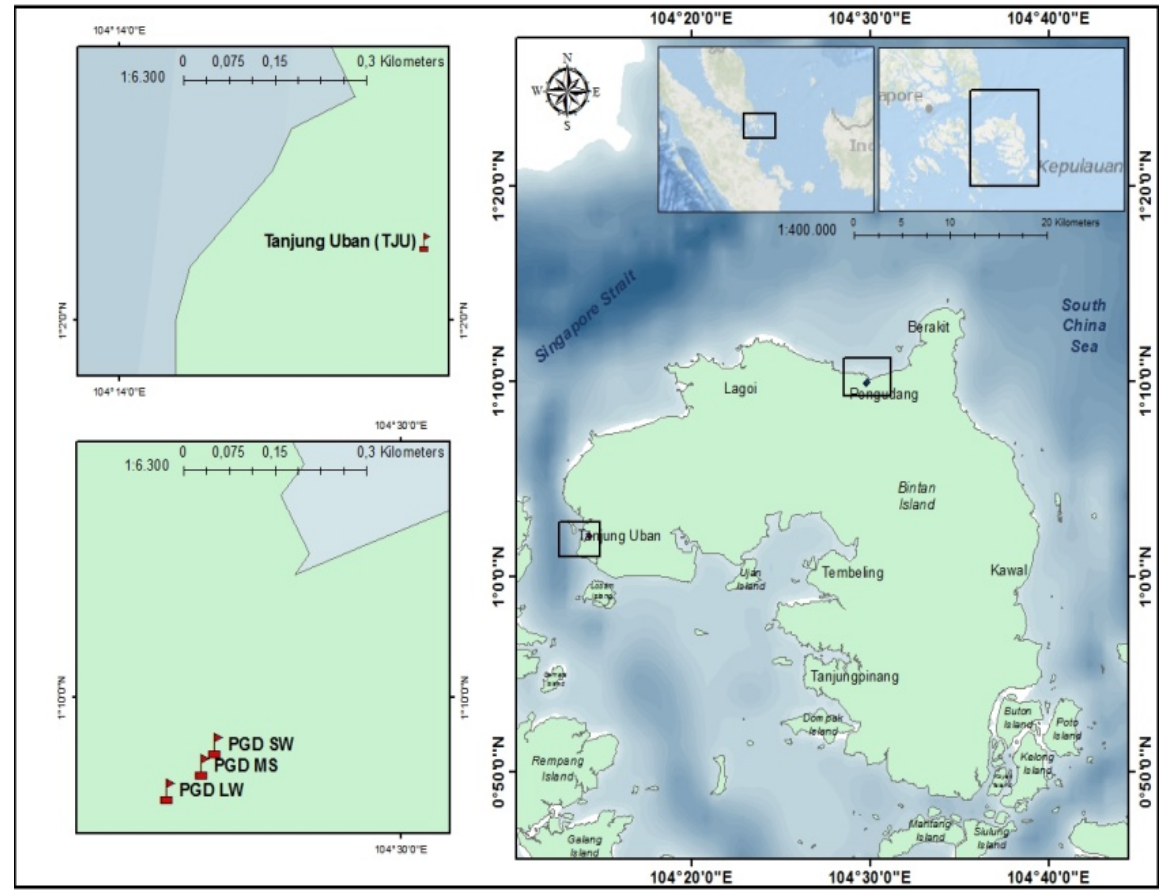

Gambar 1. Lokasi pengambilan sampel sedimen mangrove.

Figure 1. Location of mangrove sediment sampling.

Tabel 1. Koordinat geografis dan jenis spesies mangrove pada stasiun pengambilan sampel sedimen. Table 1. Geographical coordinates and type of mangrove species at the sediment sampling station.

\begin{tabular}{ccccc}
\hline \multirow{2}{*}{ Station } & \multirow{2}{*}{ Zone } & \multicolumn{2}{c}{ Coordinates } & \multirow{2}{*}{ Mangrove species } \\
\cline { 2 - 4 } & & Latitude & Longitude & \\
\hline Pengudang & Near land (A) & 1.165404 & 104.496581 & Xylocarpus granatum \\
(PGD) & Center (B) & 1.165731 & 104.497082 & Ceriops tagal \\
& Near the sea (C) & 1.166025 & 104.497277 & Rhizophora apiculata \\
$\begin{array}{c}\text { Tanjung Uban } \\
\text { (TJU) }\end{array}$ & - & 1.034389 & 104.237826 & Rhizophora apiculata \\
\hline
\end{tabular}

\section{Isolasi bakteri dari sedimen mangrove}

Bakteri diisolasi dari sedimen menggunakan metode pour plate dengan medium MA (peptone $5 \mathrm{~g} / \mathrm{L}$, yeast extract 3 $\mathrm{g} / \mathrm{L}$, agar $15 \mathrm{~g} / \mathrm{L}$, air laut $750 \mathrm{~mL} / \mathrm{L}$, akuades $250 \mathrm{~mL} / \mathrm{L}$ ), kemudian diinkubasi pada suhu $29^{\circ} \mathrm{C}$ selama tujuh hari dan dilakukan pengamatan pertumbuhan bakteri. Purifikasi isolat bakteri dengan morfologi berbeda dilakukan pada medium MA hingga memperoleh isolat tunggal.

\section{Penapisan kemampuan bakteri toleran logam berat}

Skrining kemampuan bakteri yang toleran terhadap logam berat dilakukan menggunakan medium MA dengan penambahan $100 \mathrm{ppm}$ logam berat $\mathrm{Pb}$. Cawan perlakuan diinkubasi pada suhu $29^{\circ} \mathrm{C}$ selama 24 jam. Pengamatan visual pertumbuhan bakteri dilakukan untuk menentukan kemampuan bakteri yang toleran. Isolat bakteri yang mampu tumbuh pada medium dipurifikasi kembali pada medium MA (Azad et al., 2013). Medium MA tanpa penambahan logam berat digunakan sebagai kontrol.

\section{Penentuan Minimum Inhibitory Concentration (MIC) logam berat terhadap bakteri}

Pengujian MIC dilakukan dengan menumbuhkan isolat bakteri pada medium MA dengan penambahan logam berat $\mathrm{PbCl}_{2}, \mathrm{CuSO}_{4}$, dan $\mathrm{CdCl}_{2}$ dengan konsentrasi 100 hingga 1000 ppm (setiap cawan petri mengandung jenis logam berat pada konsentrasi tertentu dengan tiga kali ulangan). Isolat bakteri diinokulasikan ke medium dan diinkubasi pada suhu $29^{\circ} \mathrm{C}$ selama 24 jam. Hasil pengamatan pertumbuhan bakteri dijadikan acuan dalam penentuan MIC (Marzan et al., 2017). 
Identifikasi molekular bakteri toleran logam berat

1. Ekstraksi DNA bakteri

Isolat diinokulasi pada media marine broth (50 mL) pada suhu $29^{\circ} \mathrm{C}$ selama 24 jam. Kultur disentrifugasi dengan kecepatan 13000 rpm selama 5 menit. Pelet ditambahi empat $\mathrm{mL}$ larutan EDTA $50 \mathrm{mM}$ dan disentrifugasi pada $13000 \mathrm{rpm}$ selama 15 menit. Pelet yang diperoleh diresuspensi ke dalam $2 \mathrm{~mL}$ bufer (sukrosa 25\%, 0,5 M EDTA, lisozim $10 \mathrm{mg} / \mathrm{mL} 100 \mu \mathrm{L}$ ) dan diinkubasi pada suhu $37^{\circ} \mathrm{C}$ selama 1 jam. Kemudian, $1200 \mu \mathrm{L} \mathrm{NaCl} 5 \mathrm{M}, 700 \mu \mathrm{L}$ 0,5 M EDTA, $1500 \mu \mathrm{L} \mathrm{20 \%} \mathrm{SDS} \mathrm{ditambahkan} \mathrm{dan}$ campuran diinkubasi pada $56^{\circ} \mathrm{C}$ selama satu jam. Kloroform sebanyak $250 \mu \mathrm{L}$ ditambahkan ke dalam campuran dan dikocok selama 20 menit, kemudian disentrifugasi pada $13000 \mathrm{rpm}$ selama satu menit. Supernatan ditempatkan ke dalam tabung baru dan ditambahkan etanol absolut (1:2). Kemudian, tabung perlakuan disentrifugasi dengan kecepatan 13000 rpm selama satu menit untuk mengendapkan molekul DNA. Pelet dicuci dengan etanol $70 \%$ dan disentrifugasi. Pelet dikeringkan dan dilarutkan menggunakan buffer TE.

2. Amplifikasi gen $16 \mathrm{~S}$ rRNA

Amplifikasi gen 16s rRNA dilakukan dengan menggunakan forward primer 27f (5'AGAGTTTGATCMTGGCTCAG-3') dan reverse primer $1492 \mathrm{r} \quad\left(5^{\prime}\right.$ TACGGHTACCTTGTTACGACTT-3').

DNA diamplifikasi dengan progam sebagai berikut: pre-denaturasi $95^{\circ} \mathrm{C}$ selama 5 menit, denaturasi pada $95^{\circ} \mathrm{C}$ selama satu menit, annealing pada $55^{\circ} \mathrm{C}$ selama 45 detik dan extention pada $72^{\circ} \mathrm{C}$ selama satu menit sebanyak 30 siklus. Kemudian diikuti post extention pada $72^{\circ} \mathrm{C}$ selama 10 menit dan cooling pada $12^{\circ} \mathrm{C}$ selama 10 menit. Semua produk yang telah teramplifikasi diseparasi menggunakan gel elektroforesis dengan 1,5\% agarose. Produk PCR dikirimkan ke Macrogen, Korea untuk analisis sekuensing.

3. Rekonstruksi pohon filogenetik isolat toleran logam berat

Hasil analisis urutan basa nitrogen gen 16s rRNA selanjutnya dipergunakan sebagai query pada BLASTn (http://www.ncbi.nlm.nih.gov/blast).

Penjajaran terhadap urutan basa nitrogen dilakukan dengan menggunakan ClustalW yang terdapat pada progam MEGA. Hasil analisis digunakan untuk menyusun pohon filogenetik dengan progam MEGA (Tamura et al., 2007). Sejarah evolusi dianalisis dengan menggunakan metode NeighborJoining dengan bootstrapping data dilakukan 1000 kali per mutasi.

\section{Hasil}

\section{Skrining kemampuan bakteri yang toleran terhadap logam berat}

Hasil isolasi bakteri dari sampel sedimen mangrove diperoleh 48 isolat yang berhasil tumbuh pada medium MA. Semua isolat diuji kemampuan toleran terhadap logam berat dan hasilnya menunjukkan bahwa 10 isolat yang mampu tumbuh pada medium dengan penambahan logam berat $\mathrm{Pb} 100$ ppm (Gambar 2).

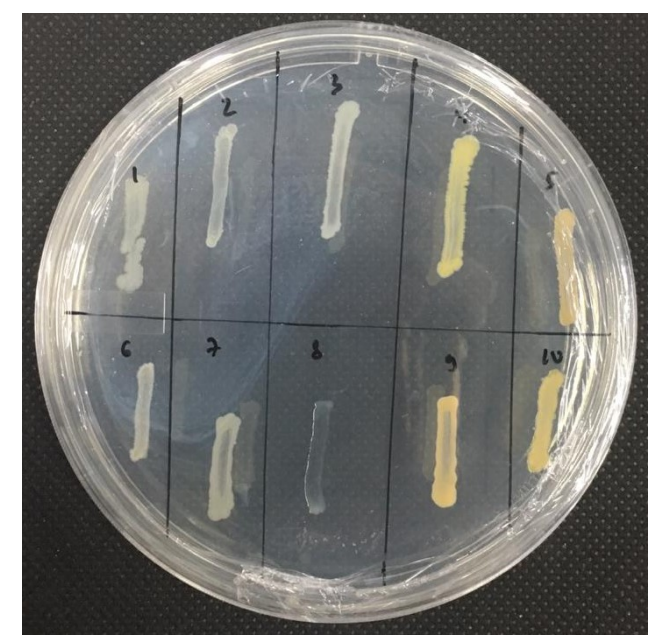

Gambar 2. Kemampuan 10 isolat bakteri tumbuh pada medium dengan penambahan $\mathrm{Pb}$ 100 ppm 1) PGD5A, 2) PGD1B, 3) TJU5, 4) PGD5C, 5) PGD9B, 6) PGD1A, 7) PGD22A, 8) TJU7, 9) PGD6C, 10) TJU1

Figure 2. The ability of 10 bacterial isolates to grow in the medium with the addition $100 \mathrm{ppm}$ of $\mathrm{Pb}$ 1) PGD5A, 2) PGD1B, 3) TJU5, 4) PGD5C, 5) PGD9B, 6) PGD1A, 7) PGD22A, 8) TJU7, 9) PGD6C, 10) TJU1

\section{Uji MIC logam berat terhadap bakteri}

MIC merupakan nilai konsentrasi minimum logam berat yang mampu menghambat pertumbuhan bakteri. Hasil pengujian MIC pada Tabel 2 menunjukkan isolat bakteri yang diisolasi dari sedimen mangrove memiliki nilai MIC 800900 ppm untuk $\mathrm{Pb}, 100-800$ ppm untuk $\mathrm{Cu}$ dan 100-200 ppm untuk Cd. 
Tabel 2. Nilai MIC logam berat terhadap isolat bakteri.

Table 2. MIC value of heavy metals against bacterial isolates.

\begin{tabular}{lccc}
\hline Bacterial & \multicolumn{3}{c}{ Heavy } \\
\cline { 2 - 4 } isolates & Pb & Cu & Cd \\
\hline PGD5A & 800 & 600 & 200 \\
PGD1B & 800 & 100 & - \\
TJU5 & 800 & 300 & - \\
PGD5C & 800 & 500 & - \\
PGD9B & 900 & 600 & 200 \\
PGD1A & 800 & 700 & 100 \\
PGD22A & 800 & 100 & - \\
TJU7 & 800 & - & - \\
PGD6C & 900 & 300 & - \\
TJU1 & 800 & 800 & - \\
\hline
\end{tabular}

Penelitian menunjukkan bahwa 10 isolat bakteri toleran terhadap logam berat $\mathrm{Pb}$ pada konsentrasi 700 ppm sedangkan PGD9B dan
PGD6C hingga 800 ppm; isolat PGD1A, PGD5A, PGD9B dan TJU1 toleran $\mathrm{Cu}$ pada konsentrasi 500-700 ppm; sedangkan isolat PGD5A dan PGD9B toleran terhadap Cd pada $100 \mathrm{ppm}$. Hasil menunjukkan terdapat tiga isolat bakteri yang bersifat toleran terhadap semua jenis logam berat yang diujikan yaitu PGD1A, PGD5A, dan PGD9B.

\section{Identifikasi molekular bakteri toleran logam berat}

Urutan sekuen tiga isolat toleran logam berat disejajarkan dengan strain bakteri referensi di GenBank. Analisis BLAST menunjukkan bahwa ketiga strain toleran logam berat berasal dari filum Proteobacter dan Firmicutes yang terdiri dari genus Vibrio, Bacillus, dan Halobacillus. Rekonstruksi pohon filogenetik dibuat dengan menggunakan urutan sekuen gen 16S rRNA seperti yang ditunjukkan pada Gambar 3.

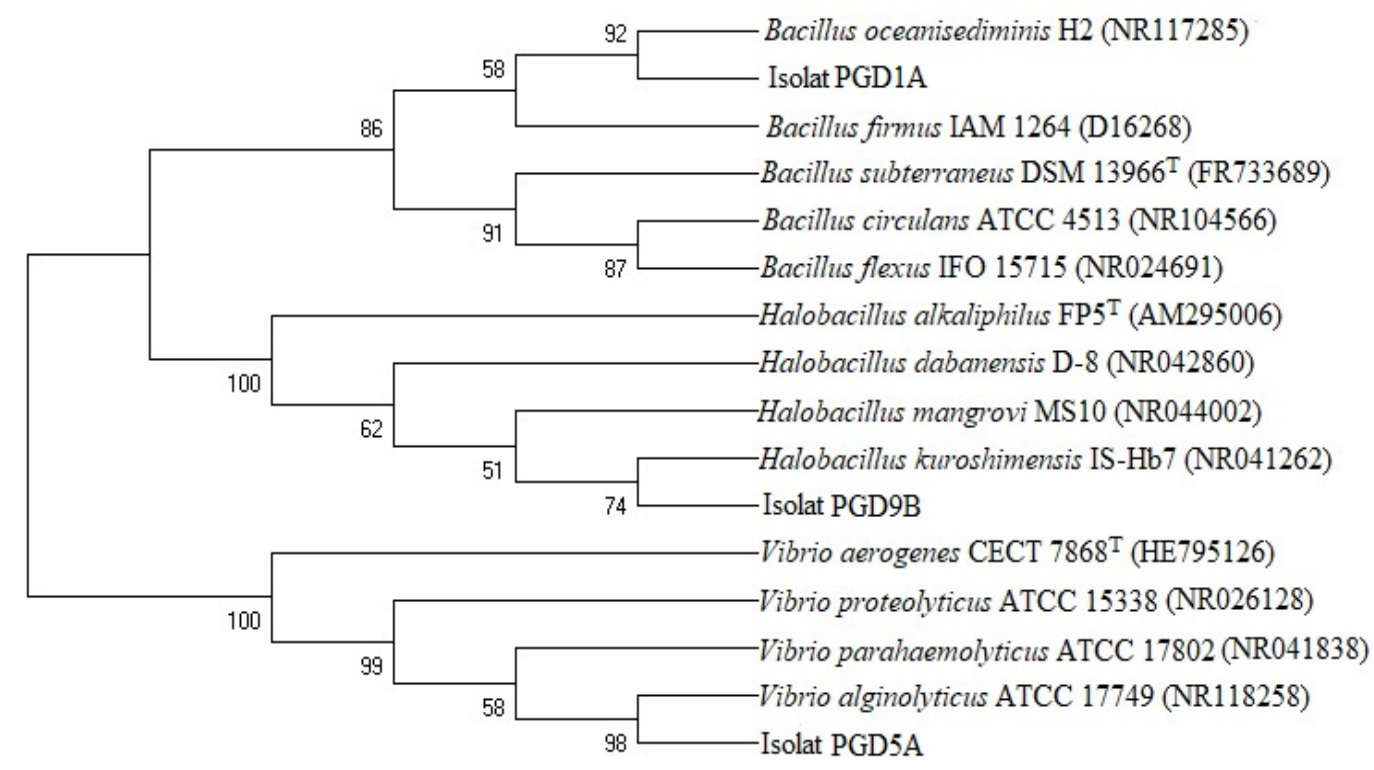

Gambar 3. Pohon filogenetik berdasarkan urutan gen 16S rRNA dari bakteri toleran logam berat menggunakan metode Neighbor-Joining. Nilai bootstrap dari 1000 ulangan ditunjukkan di titik percabangan.

Figure 3. Phylogenetic tree based on 16S rRNA gene sequences of heavy metal tolerant bacterial using the Neighbor-Joining method. Bootstrap from 1000 replicates is indicated at the node.

\section{Pembahasan}

Mikroorganisme memainkan peran penting dalam bioremediasi logam berat dari tanah yang terkontaminasi dan air limbah. Pendekatan berbasis mikroorganisme untuk menghilangkan dan memulihkan logam beracun dari limbah industri dapat bernilai lebih ekonomis dan efisien daripada metode fisikokimia. Zouboulis et al. (2004) melaporkan bahwa beberapa jenis biomassa mikroogranisme dapat mempertahankan jumlah ion logam yang relatif tinggi dalam proses yang dikenal sebagai biosorpsi. Penelitian menunjukkan bahwa bakteri 
de Fretes et al.

dapat mengikat logam dan memiliki kemampuan resisten terhadap logam berat. Berbagai mekanisme telah dimanfaatkan untuk pengembangan resistensi logam pada mikroorganisme (François et al., 2012). Mikroorganisme dapat berinteraksi dengan logam berat melalui banyak mekanisme, beberapa di antaranya dapat digunakan sebagai dasar untuk strategi bioremediasi potensial. Mekanisme dimana mikroorganisme bekerja pada logam berat termasuk biosorpsi (penyerapan logam ke permukaan sel oleh mekanisme fisikokimia), bioleaching (mobilisasi logam berat melalui ekskresi asam organik atau reaksi metilasi), biomineralisasi (imobilisasi logam berat melalui pembentukan sulfida yang tidak larut atau kompleks polimerik), akumulasi intraseluler dan transformasi enzim yang dikatalisis (Lloyd, 2002).

Hasil penelitian menujukkan bahwa setiap mikroorganisme memiliki kemampuan ketahanan terhadap logam berat yang berbeda-beda. SáPereiraa et al. (2009) menjelaskan bahwa mikroorganisme dapat bertahan pada konsentrasi logam berat yang tinggi tergantung pada aktivitas bakteri tersebut mampu menghilangkan efek beracun dari logam berat pada daerah yang terkontaminasi. Penelitian Anyanwu et al. (2011) menunjukkan bahwa bakteri heterotrofik mampu toleran terhadap merkuri, seng, dan nikel pada konsentrasi 300-500 $\mu \mathrm{g} / \mathrm{g}$ tanah. Hal ini menunjukkan bahwa pertumbuhan bakteri menunjukkan respon yang berbeda dipengaruhi oleh jenis dan konsentrasi logam berat. Oleh karena itu, penentuan nilai MIC penting dilakukan agar mengetahui besar konsentrasi dari jenis logam berat berbeda terhadap pertumbuhan bakteri.

Identifikasi melokular isolat bakteri toleran logam berat dengan sekuen gen 16S rRNA diperoleh genus Bacillus, Halobacillus, dan Vibrio. Isolat dari genus Bacillus telah banyak dilaporkan mampu tahan dan dapat melakukan detoksifikasi logam berat (Nithya \& Pandian, 2010; Monachese et al., 2012; Syed \& Chinthala, 2015). Anggota genus Bacillus, Halobacillus, Oceanobacillus, Exiguobacterium, Serratia, Brevundimonas, Vibrio, dan Staphylococcus memiliki resistensi terhadap logam berat $\mathrm{Cu}^{2+}$, $\mathrm{Pb}^{2+}, \mathrm{Cd}^{2+}, \mathrm{Zn}^{2+}, \mathrm{Hg}^{2+}$; serta berperan sebagai plant growth promoting bacteria (Bian et al., 2011). Ketiga isolat ini diharapkan dapat dikembangkan agar memberikan kontribusi bagi penyelesaian masalah lingkungan khususnya pencemaran logam berat.

\section{Kesimpulan}

Pencarian isolat bakteri yang toleran terhadap logam berat penting dilakukan untuk monitoring pencemaran pada ekosistem. Penelitian menunjukkan bahwa terdapat 10 isolat bakteri dapat toleran terhadap logam berat pada jenis dan konsentrasi berbeda. Nilai MIC logam berat terhadap bakteri yaitu $800-900$ ppm untuk $\mathrm{Pb}$, 100-800 ppm untuk $\mathrm{Cu}$ dan $100-200$ ppm untuk Cd. Terdapat tiga isolat bakteri yang memiliki kemampuan toleran yang tinggi terhadap logam berat $\mathrm{Pb}, \mathrm{Cu}$, dan $\mathrm{Cd}$ yaitu Bacillus oceanisediminis PGD1A, Vibrio alginolyticus PGD5A, dan Halobacillus kuroshimensis PGD9B. Isolat bakteri toleran logam berat tersebut dapat diuji sebagai agen hayati dalam proses bioremediasi logam berat dari ekosistem tercemar.

\section{Persantunan}

Penelitian ini didanai dari dana penelitian Prioritas LIPI melalui program COREMAP-CTI Tahun Anggaran 2018.

\section{Daftar Pustaka}

Asha, L. P., \& Sandeep, R. S. (2013). Review on Bioremediation-Potential Tool for Removing Environmental Pollution. International Journal of Basic and Applied Chemical Sciences, 3(3), 21-33.

Anyanwu, C. N. (2011). Soil Bacterial Response to Introduced Metal Stress. International Journal of Basic \& Applied Sciences, 11(1), 73-76.

Azad, A. K., Nahar, A., Hasan, M. M., Islam, K., Azim, M. F., Hossain, M. S., Rahman, M. R., Ojha, R. K., Mahmud, G. M. S., \& Kayes, R. (2013). Fermentation of municipal solid wastes by bacterial isolates for production of raw protein degrading proteases. Asian Journal of Microbiology, Biotechnology, Environmental Science, 15, 365-374.

Bian, G. K., Zhang, Y., Qin, S., \& Jiang, J. (2011). Isolation and biodiversity of heavy metal tolerant endophytic bacteria from halotolerant plant spesies located in coastal shoal of Nantong. Acta Microbiologica Sinica, 51(11), 1538-1547.

Cheng, S. (2003). Heavy metal pollution in China: origin, pattern and control. Environmental Science and Pollution Research, 10(3), 192-198.

Dias, A. C. F., Andreote, F. D., \& DiniAndreoteetal, F. (2009). Diversity and 
biotechnological potential of culturable bacteria from Brazilian mangrove sediment. World Journal of Microbiology and Biotechnology, 25(7), 1305-1311.

Dias, A. C. F., Andreote, F. D., Rigonato, J., Fiore, M. F., Melo, I. S., \& Araújo, W. L. (2010). The bacterial diversity in a Brazilian non-disturbed mangrove sediment. Antonie van Leeuwenhoeck, 98, 541-551.

François, F., Lombard, C., Guigner, J. M., Soreau, P., Brian-Jaisson, F., Martino, G., \& Pignol, D. (2012). Isolation and characterization of environmental bacteria capable of extracellular biosorption of mercury. Applied and Environmental Microbiology, 78(4), 1097-1106.

Holguin, G., Vazquez, P., \& Bashan, Y. (2001). The role of sediment microorganisms in the productivity, conservation, and rehabilitation of mangrove ecosystems: an overview. Biology and Fertility of Soils, 33(4), 265-278.

Lloyd, J. R. (2002). Bioremediation of metals: The application of microorganisms that make and break minerals. Microbiology Today, 29, 67-69.

Marzan, L. W., Hossain, M., Mina, S. A., Akter, Y., Masudul, A. M., \& Chowdhury, A. (2017). Isolation and biochemical characterization of heavy-metal resistant bacteria from tannery effluent in Chittagong city, Bangladesh: Bioremediation viewpoint. Egyptian Journal of Aquatic Research, 43(1), 65-74.

Monachese, M., Burton, J. P., \& Reida, G. (2012). Bioremediation and Tolerance of Humans to Heavy Metals through Microbial Processes: a Potential Role for Probiotics?.
Applied and Environmental Microbiology, 78(18), 6397-6404.

Monteiro, C. M., Castro, P. M., \& Malcata, F. X. (2012). Metal uptake by microalgae: Underlying mechanisms and practical applications. Biotechnology Progress, 28(2), 299-311.

Nithya, C. \& Pandian, S. K. (2010). Isolation of heterotrophic bacteria from Palk Bay sediments showing heavy metal tolerance and antibiotic production. Microbiological Research, 165, 578-593.

Sá-Pereiraa, P., Rodriguesab, M., Simõesa, F., \& Dominguesb, L. (2009). Bacterial Activity in Heavy Metals Polluted Soils: Metal Efflux Systems in Native Rhizobial Strains. Geomicrobiology Journal, 26, 281-288.

Syed, S. \& Chinthala, P. (2015). Heavy Metal Detoxification by Different Bacillus Species Isolated from Solar Salterns. Scientifica, 2015, 1-8.

Taketani, R. G., Franco, N. O., Rosado, A. S., \& van Elsas, J. D. (2010). Microbial community response to a simulated hydrocarbon spill in mangrove sediments. Journal of Microbiology, 48, 7-15.

Tamura, K., Dudley, J., Nei, M., \& Kumar, S. (2007). MEGA 4: Molecular Evolutionary Genetics Analysis (MEGA) Software Version 4.0. Molecular Biology and Evolution, 24, 1596-1599.

Thassitou, P. \& Arvanitoyannis, I. (2001). Bioremediation: a novel approach to food waste management. Trends in Food Science and Technology, 12(5), 185-196.

Zouboulis, A. I., Loukidou, M. X., \& Matis, K. A. (2004). Biosorption of toxic metals from aqueous solutions by bacteria strains isolated from metal-polluted soils. Process Biochemistry, 39(8), 909-916. 